\title{
EKSISTENSI DAN INTEGRITAS BAWASLU DALAM PENANGANAN SENGKETA PEMILU
}

\author{
Muhammad Ja'far \\ STIK Indonesia Jaya Kampus Parigi \\ Email : muhjafar425@gmail.com
}

\begin{abstract}
As an institution that is presented to oversee the implementation of elections, the General Election Supervisory Board is expected the role and integrity so that the implementation of elections can run as expected and running smoothly. The formulation of the issues raised is how the role of Election Supervisory Body in handling election disputes in Indonesia. The research method used is juridical normative with primary law material. The result of the research is that the Election Supervisory Board has an important role as the guard of the general election as mandated in the Law on the Implementation of General Election, it is mentioned that the function of Election Supervisor is as described in the duties, authorities and obligations of General Election Supervision.
\end{abstract}

Keywords: Election Supervisory Board, Dispute Settlement.

\begin{abstract}
Abstrak: Sebagai lembaga yang dihadirkan untuk mengawasi penyelenggaraan pemilu, Badan Pengawas Pemilu (Bawaslu) sangat diharapkan peran dan integritasnya agar pelaksanaan pemilu dapat berjalan sesuai dengan yang diharapkan dan berjalan lancar. Rumusan masalah yang diangkat adalah bagaimanaperan Bawaslu dalam penanganan sengketa pemilu menurut aturan hukum di Indonesia.Metode penelitian yang digunakan adalah normatif-yuridis dengan metode analisis adalah deskriptif analitis.Hasil penelitiannya adalah Bawaslu mempunyai peran yang penting dalam rangka sebagai pengawal Pemilu sesuai dengan yang diamanatkan di dalam Undang-Undang tentang Penyelenggaraan Pemilu, disebutkan bahwa fungsi Pengawas Pemilu yang dijabarkan dalam tugas, wewenang dan kewajiban Pengawas Pemilu.
\end{abstract}

Kata kunci: BadanPengawasPemilu, SengketaPemilihanUmum 


\section{LATAR BELAKANG}

Badan Pengawas Pemilu (Bawaslu) adalah lembaga penyelenggara Pemilu yang mengawasi Penyelenggaraan Pemilu di seluruh wilayah negara kesatuan Republik Indonesia. ${ }^{1}$ Sebagai lembaga yang perannya memiliki kewenangan basar tidak hanya sebagai pengawas namun juga sebagai eksekutor hakim pemutus perkara berdasarkan amanat dalam UndangUndang Nomor 7 Tahun 2017 tentang Pemilihan Umum (Pemilu).

Kedepan, integritas Bawaslu akan diuji eksistensi strategisnya mengawal pemilu yang berintegritas bagi kemajuan bangsa. Dalam konteks Indonesia yang sedang membangun peradaban politik yang sehat, pelaksanaan pemilu tanpa hadirnya pengawasan secara struktural dan fungsional yang kokoh berpotensi besar akan menimbulkan hilangnya hak pilih warga negara, maraknya politik uang, kampanye hitam, dan pemilu yang tidak sesuai aturan. Dampak lanjutan pemilu yang tidak berintegritas adalah timbulnya sengketa dan gugatan hasil pemilu. Selain itu, pesta demokrasi yang berbiaya tinggi, tetapi hanya akan menghasilkan pemimpin yang legalitas dan legitimasinya diragukan. Potensi bahaya selanjutnya adalah

\footnotetext{
Ketentuan Umum Pasal 1 (6) Undang-Undang Nomor 18 Tahun 2017 tentang Tata Cara Penyelesaian Sengketa Proses Pemilhan Umum
}

tumbuhnya konflik politik yang tidak berkesudahan.

Pemilu sebagai suatu mekanisme demokrasi sesungguhnya didesain untuk mentransformasikan sifat konflik di masyarakat menjadi ajang politik yang kompetitif dan penuh integritas melalui pemilihan umum yang berjalan lancar, tertib, dan berkualitas. Pemilu merupakan sarana perwujudan kedaulatan rakyat guna menghasilkan pemerintahan Negara yang demokratis berdasarkan Pancasila dan Undang-Undang Dasar 1945, sesuai Pasal 1 ayat (2) yang berbunyi, "Kedaulatan berada ditangan rakyat dan dilaksanakan menurut Undang-Undang Dasar". Pasal 22E Ayat (1) UUD 1945 menggariskan enam kriteria pemilu demokratis, yaitu langsung, umum, bebas, rahasia, jujur, dan adil. Selanjutnya, UndangUndang Pemilu menambah dua kriteria lagi, yakni transparan dan akuntabel. Pemilihan umum telah menjadi fenomena global dan telah dipraktikkan, baik di negara yang telah maju demokrasinya maupun negara yang masih dalam proses transisi menuju demokrasi. Namun demikian, fenomena pemilu di berbagai negara, termasuk negara maju, masih menunjukkan bahwa pemilu tidak bisa lepas dari berbagai pelanggaran dan kecurangan (electoral malpractices). Dalam konteks inilah, konsep integritas 
pemilu menjadi penting karena napas yang menjiwai pemilu adalah politik, yang memiliki sifat dasar menghalalkan cara untuk mencapai tujuan dan kekuasaan.

Sejatinya, pemilu harus berjalan baik secara prosedural dan substansial. Pemilu baik secara prosedural jika prasyaratnya sudah terpenuhi dan pemilu berhasil secara substansial jika tujuannya tercapai. Prasyarat pemilu menggariskan adanya kebebasan dalam memilih, terwujudnya partisipasi masyarakat, dan arena berkompetisi politik yang fair. Adapun tujuan yang ingin dicapai dengan pelaksanaan pemilu adalah terpilihnya pemimpin yang menjadi kehendak rakyat. Pemimpin amanah yang mampu mewujudkan kesejahteraan dan keadilan.

Salah satu fungsi Bawaslu adalah melakukan pengawasan tahapan dan pencegahan pelanggaran pemilu. Terdapat fungsi Bawaslu yang strategis dan signifikan, yakni bagaimana menghindari potensi pelanggaran pemilu muncul dengan menjalankan strategi pencegahan yang optimal. Bawaslu juga diharapkan mampu melakukan penindakan tegas, efektif, dan menjadi hakim pemilu yang adil. Disinilah, integritas bawaslu akan selalu diuji karena dia akan menangani beberapa elemen yang terdapat dalam pemilu karena elemen ini juga akan sarat akan kepentingan satu sama lain, adapun rumusan masalah dalam tulisan ini adalah bagaimana peran Bawaslu dalam penanganan sengketa pemilu menurut aturan hukum di Indonesia?

\section{METODE PENELITIAN}

Penelitian ini merupakan penelitian hukumyuridis-normatif sehingga dihadirkan data sekunder yaitu data yang berasal dari bahan pustaka. ${ }^{2}$ Metode pengumpulan datanya adalah melalui studi kepustakaan yaitu dengan meneliti dan menggali bahan-bahan hokum atau datadata tertulis berupa kitab-kitab perundangundangan, buku-buku, jurnal, makalah dan lainnya yang terkait dengan permasalahan

yang akan diteliti. Metode analisis yang digunakan adalah deskriptif analitis, yang artinya memberikan analisis gambaran terkait permasalahan yang diteliti.

\section{PEMBAHASAN}

\section{Sejarah Pengawasan Pemilu}

Dalam sejarah pelaksanaan pemilu di Indonesia, istilah pengawasan pemilu sebenarnya baru muncul pada era 1980-an. Pada pelaksanaan Pemilu yang pertama kali dilaksanakan di Indonesia pada 1955 belum dikenal istilah pengawasan Pemilu. Pada era tersebut terbangun trust di seluruh

\footnotetext{
${ }^{2}$ SoejonoSoekanto,

PengantarPenelitianHukum, (Jakarta: UI Press, 2008) hlm. 11.
} 
peserta dan warga negara tentang penyelenggaraan Pemilu yang dimaksudkan untuk membentuk lembaga parlemen yang saat itu disebut sebagai Konstituante.

Walaupun pertentangan ideologi pada saat itu cukup kuat, tetapi dapat dikatakan sangat minim terjadi kecurangan dalam pelaksanaan tahapan, kalaupun ada gesekan terjadi di luar wilayah pelaksanaan Pemilu. Gesekan yang muncul merupakan konsekuensi logis pertarungan ideologi pada saat itu. Hingga saat ini masih muncul keyakinan bahwa Pemilu 1955 merupakan Pemilu di Indonesia yang paling ideal. Kelembagaan Pengawas Pemilu baru muncul pada pelaksanaan Pemilu 1982 dengan nama Panitia Pengawas Pelaksanaan Pemilu (Panwaslak Pemilu). Pada saat itu sudah mulai muncul distrust terhadap pelaksanaan Pemilu yang mulai dikooptasi oleh kekuatan rezim penguasa. Pembentukan Panwaslak Pemilu pada Pemilu 1982 dilatari oleh protes-protes atas banyaknya pelanggaran dan manipulasi penghitungan suara yang dilakukan oleh para petugas pemilu pada Pemilu 1971. Karena palanggaran dan kecurangan pemilu yang terjadi pada Pemilu 1977 jauh lebih masif. Protes-protes ini lantas direspon pemerintah dan DPR yang didominasi Golkar dan ABRI. Akhirnya muncullah gagasan memperbaiki undang-undang yang bertujuan meningkatkan 'kualitas' Pemilu 1982. Demi memenuhi tuntutan PPP dan PDI, pemerintah setuju untuk menempatkan wakil peserta pemilu ke dalam kepanitiaan pemilu. Selain itu, pemerintah juga mengintroduksi adanya badan baru yang akan terlibat dalam urusan pemilu untuk mendampingi Lembaga Pemilihan Umum (LPU).

Pada era reformasi, tuntutan pembentukan penyelenggara Pemilu yang bersifat mandiri dan bebas dari kooptasi penguasa semakin menguat. Untuk itulah dibentuk sebuah lembaga penyelenggara Pemilu yang bersifat independen yang diberi nama Komisi Pemilihan Umum (KPU). Hal ini dimaksudkan untuk meminimalisasi campur tangan penguasa dalam pelaksanaan Pemilu mengingat penyelenggara Pemilu sebelumnya, yakni LPU, merupakan bagian dari Kementerian Dalam Negeri (sebelumnya Departemen Dalam Negeri). Di sisi lain lembaga pengawas pemilu juga berubah nomenklatur dari Panwaslak Pemilu menjadi Panitia Pengawas Pemilu (Panwaslu).

Perubahan mendasar terkait dengan kelembagaan Pengawas Pemilu baru dilakukan melalui Undang-Undang Nomor 12 Tahun 2003. Menurut Undang-Undang (UU) ini dalam pelaksanaan pengawasan 
Pemilu

dibentuk

sebuah

lembaga adhoc terlepas dari struktur KPU yang terdiri dari Panitia Pengawas Pemilu, Panitia Pengawas Pemilu Provinsi, Panitia Pengawas Pemilu Kabupaten/Kota, dan Panitia Pengawas Pemilu Kecamatan. Selanjutnya kelembagaan pengawas Pemilu dikuatkan melalui Undang-Undang Nomor 22 Tahun 2007 tentang Penyelenggara Pemilu dengan dibentuknya sebuah lembaga tetap yang dinamakan Badan Pengawas Pemilu (Bawaslu). Adapun aparatur Bawaslu dalam pelaksanaan pengawasan berada sampai dengan tingkat kelurahan/desa dengan urutan Panitia Pengawas Pemilu Provinsi, Panitia Pengawas Pemilu Kabupaten/Kota, Panitia Pengawas Pemilu Kecamatan, dan Pengawas Pemilu Lapangan (PPL) di tingkat kelurahan/desa. Berdasarkan ketentuan Undang-Undang Nomor 22 Tahun 2007, sebagian kewenangan dalam pembentukan Pengawas Pemilu merupakan kewenangan dari KPU. Namun selanjutnya berdasarkan Keputusan Mahkamah Konstitusi terhadap judicial review yang dilakukan oleh Bawaslu terhadap UndangUndang Nomor 22 Tahun 2007, rekrutmen pengawas Pemilu sepenuhnya menjadi kewenangan dari Bawaslu. Kewenangan utama dari Pengawas Pemilu menurut Undang-Undang Nomor 22 Tahun 2007 adalah untuk mengawasi pelaksanaan tahapan pemilu, menerima pengaduan, serta menangani kasus-kasus pelanggaran administrasi, pelanggaran pidana pemilu, serta kode etik.

Dinamika kelembagaan pengawas Pemilu ternyata masih berjalan dengan terbitnya Undang-Undang Nomor 15 Tahun 2011 tentang Penyelenggara Pemilu. Secara kelembagaan pengawas Pemilu dikuatkan kembali dengan dibentuknya lembaga tetap Pengawas Pemilu di tingkat provinsi dengan nama Badan Pengawas Pemilu Provinsi (Bawaslu Provinsi). Selain itu pada bagian kesekretariatan Bawaslu juga didukung oleh unit kesekretariatan eselon I dengan nomenklatur Sekretariat Jenderal Bawaslu. Selain itu pada konteks kewenangan, selain kewenangan sebagaimana diatur dalam Undang-Undang Nomor 22 Tahun 2007, Bawaslu berdasarkan Undang-Undang Nomor 15 Tahun 2011 juga memiliki kewenangan untuk menangani sengketa Pemilu. $^{3}$

\section{Fungsi dan Peran Bawaslu}

Perancangan sebuah sistem pemilu dengan demikian harus melakukan proses cermat memprioritaskan kriterian mana yang paling penting bagi suatu konteks politik tertentu sebelum beranjak untuk

http://pl.bawaslu.go.id/pages/read/sejarahpengawasan-pemilu, diakses pada tanggal 20 Juni 2018. 
menilai sistem mana yang akan memberikan hasil terbaik. Langkah bermanfaat yang perlu ditempuh pertama kali adalah membuat daftar hal-hal terbaik. Langkah bermanfaat yang perlu ditempuh pertama kali adalah membuat daftar hal-hal yang harus dihindari dengan segala cara seperti malapetaka politik yang bisa merusak demokrasi. ${ }^{4}$

Selanjutnya, di dalam modul pengawasan Pemilu yang disusun oleh Bawaslu, Pemilu dikatakan demokratis jika memenuhi beberapa persyaratan dasar, setidaknya ada lima (5) parameter universal dalam menentukan kadar demokratis, yakni: ${ }^{5}$ pertama, Universalitas (Universality), Karena nilai-nilai demokrasi merupakan nilai universal, maka pemilu yang demokratis juga harus dapat diukur secara universal. Artinya konsep, sistem, prosedur, perangkat dan pelaksanaan pemilu harus mengikuti kaedah kaedah demokrasi universal itu sendiri.

Kedua, Kesetaraan (Equality), Pemilu yang demokratis harus mampu menjamin kesetaraan antara masingmasing konstentan untuk berkompetensi. Salah satu unsur penting yang akan

\footnotetext{
${ }^{4}$ Andrew Reynolds, et.al., Desain Sistem Pemilu: Buku Panduan Baru Internasional IDEA, Swedia, International IDEA, 2016, hlm. 16-17

${ }^{5}$ Modul Pengawasan, Badan Pengawas Pemilu-Indonesia Corruption Watch, Jakarta, Bawaslu, 2009, hlm. 7-8.
}

mengganjal prinsip kesetaraan ini adalah timpangnya kekuasaan dan kekuatan sumberdaya yang dimiliki konstestan pemilu. Secara sederhana, antara partai politik besar dengan yang kecil yang bari lahir tentunya memiliki kesenjangan sumber daya yang lebar. Oleh karena itu, regulasi pemilu seharusnya dapat meminimalisir terjadinya political inequality.

Ketiga, Kebebasan (Freedom), dalam pemilu yang demokratis, para pemilih harus bebas menentukan sikap politiknya tanpa adanya tekanan, intimidasi, imingiming pemberian hadiah tertentu yang akan mempengaruhi pilihan mereka. Jika hal demikian terjadi dalam pelaksanaan pemilu, maka perlakuannya harus diancam dengan sanksi pidana pemilu yang berat. Keempat, Kerahasiaan (Secrecy), apapun pilihan politik yang diambil oleh pemilih, tidak boleh diketahui oleh pihak manapun bahkan, oleh panitia pemilihan. Kerahasiaan sebagai suatu prinsip sangat terkait dengan kebebasan seseorang dalam memilih.

$$
\text { Terkahir, Transparansi }
$$

(Transparency), transparansi ini terkait dua hal, yakni kinerja dan pengguaan sumberdaya. KPU harus dapat meyakinkan public dan peserta pemilu bahwa mereka adalah lembaga independen yang akan 
menjadi pelaksana pemilu yang adil dan tidak berpihak (imparsial).

Selain itu, salah satu prasyarat penting dalam penyelenggaraan Pemilu di Negara demokrasi adalah bahwa penyelenggaraan pemilu dilaksanakan oleh lembaga yang mandiri dari pemerintah. ${ }^{6}$ UUD $1945^{7}$ mempertegas hal tersebut, yang menggariskan bahwa "pemilihan umum diselenggarakan oleh suatu komisi pemilihan umum yang bersifat nasional, tetap dan mandiri”. Sifat nasional mencerminkan bahwa wilayah kerja dan tanggung jawab KPU sebagai penyelenggara pemilihan umum mencakup seluruh wilayah Negara kesatuan Republik Indonesia. Sifat tetap menunjukkan KPU sebagai lembaga yang menjalankan tugas secara berkesinambungan meskipun dibatasi oleh masa jabatan tertentu. Sifat mandiri menegaskan bahwa KPU dalam menyelenggarakan dan melaksanakan pemilihan umum bebas dari pengaruh pihak manapun.Sedangkan pengawasan dari penyelenggaraan Pemilu tersebut diberikan kepada Badan Pengawasa Pemilu (Bawaslu) dan jajaran dibawahnya Panitia Pengawas Pemilihan Umum (Panwaslu).

\footnotetext{
${ }^{6}$ Ahmad Nadir, Pilkada Langsung dan Masa Depan Demokrasi di Indonesia, Malang : Averroes Press, 2005 hlm. 156

${ }^{7}$ Pasal 22 Ayat 5 Undang-UndangDasar 1945.
}

Di dalam Undang-Undang Nomor 22 tahun 2007 tentang Penyelenggaraan Pemilu ${ }^{8}$, disebutkan bahwa fungsi Pengawas Pemilu yang dijabarkan dalam tugas, wewenang dan kewajiban Pengawas Pemilu. Berkaitan dengan tugas pengawasan pemilu ada pembagian tugas pengawasan pemilu yang dapat dijelaskan sebagai berikut : Bawaslu melakukan pengawasan terhadap seluruh tahapan penyelenggaraan Pemilu, Panwaslu Provinsi mengawasi tahapan penyelenggaraan Pemilu di wilayah provinsi, Panwaslu kabupaten/kota mengawasi penyelenggaraan Pemilu di wilayah kabupaten/kota, Panwaslu Kecamatan mengawasi tahapan penyelenggaraan Pemilu di wilayah kecamatan, Pengawas Pemilu Lapangan mengawasi tahapan penyelenggaraan Pemilu ditingkat desa/kelurahan, Pengawas Pemilu Luar Negeri mengawssi tahapan penyelenggaraan Pemilu di luar negeri.

Adapun tugas dan wewenang Pengawas Pemilu dapatlah dijelaskan secara umum sebagai berikut : Mengawasi tahapan penyelenggaraan pemilu, menerima laporan dugaan pelanggaran perundang-undangan pemilu, menyampaikan temuan dan laporan kepada KPU/KPU provinsi/KPU kabupaten/kota atau kepolisian atau instansi lainnya untuk

\footnotetext{
${ }^{8}$ Undang-UndangNomor 22 Tahun 2007 tentang Penyelenggaraan Pemilu
} 
ditindaklanjuti, Mengawasi tindak lanjut rekomendasi, mengawasi pelaksanaan sosialisasi penyelenggaraan Pemilu; dan melaksanakan ; Tugas dan wewenang lain ditetapkan oleh undang-undang (untuk Bawaslu, Panwaslu Provinsi, dan Panwaslu kabupaten/kota), melaksanakan tugas lain dari Panwaslu Kecamatan (untuk Pengawas Pemilu lapangan), dan melaksanakan tugas lain dari Bawaslu (untuk Pengawas Pemilu Luar Negeri).

Dalam melaksanakan tugas, Bawaslu, Panwaslu Provinsi dan Panwaslu Kabupaten/Kota berwenang ; Memberikan rekomendasi kepada KPU untuk menonaktifkan sementara dan/atau mengenakan sanksi administratif atas pelanggaran; dan Memberikan rekomendasi kepada yang berwenang atas temuan dan laporan terhadap tindakan yang mengandung unsur tindak pidana Pemilu.

\section{Solusi dalam Tantangan Bawaslu}

Setelah melalui dinamika yang cukup panjang sejak dibentuknya pansus RUU Penyelenggaraan Pemilu pada 28 Oktober 2016, akhirnya RUU tersebut baru dapat disahkan secara aklamasi pada tanggal 21 Juli 2017 dalam rapat paripurna DPR-RI meski rapat tersebut masih diwarnai dengan aksi walk-out 4 fraksi di DPR yaitu fraksi Gerindra, fraksi PAN, fraksi
Demokrat dan fraksi PKS. Secara umum Undang-Undang Penyelenggaraan Pemilu tersebut mengatur tentang penyelenggara pemilu, penyelenggaraan pemilihan umum legislatif, dan penyelenggaraan pemilihan umum presiden dan wakil presiden.

Beberapa perubahan signifikan yang sempat menjadi isu krusial pembahasan RUU diantaranya menyangkut kedudukan dan kewenangan penyelenggara pemilu. Lembaga Pengawas Pemilu sebagai salah satu unsur penyelenggara pemilu menjadi lembaga penyelenggara yang semakin kuat kedudukannya dalam undang-undang tersebut.

Secara struktural kini pembentukan Badan Pengawas Pemilu yang bersifat tetap atau permanen akan sampai ke tingkat kabupaten/kota seperti struktur lembaga KPU yang sejak lama telah bersifat tetap sampai ke tingkat kabupaten/kota. Penerapan peningkatan struktur kelembagaan Bawaslu yang diamanatkan dalam undang-undang tersebut paling cepat baru dapat diterapkan setahun setelah Undang-Undang Penyelenggaraan Pemilu disahkan oleh DPR. Bersamaan itu pula penambahan jumlah anggota Bawaslu tingkat provinsi dan kabupaten/kota dari 3 menjadi 5-7 komisioner akan disesuaikan dengan tingkat coverage yang diawasi. 
Dengan bertambahnya kewenangankewenangan strategis yang diamanatkan undang-undang kepada Bawaslu seperti kewenangan untuk menerima laporan, memeriksa, dan memutus pelanggaran TSM (Terstruktur, Sistematis, dan Masif), hal tersebut menjadi tantangan bagi lembaga ini untuk memaksimalkan peran dan fungsi yudikatifnya untuk menciptakan sebuah formulasi hukum yang tepat sekaligus mengukur dan mengantisipasi dampak sosial politik atas penerapan sanksi pembatalan calon atau peserta pemilihan ditengah suasana dengan tensi politik yang bergejolak. Begitupun halnya dengan kewenangan untuk menerima dan memutus permohonan sengketa pemilihan juga menuntut Bawaslu di tengah waktu tahapan yang berhimpit-himpitan untuk segera memastikan hadirnya para pengawas pemilu di daerah yang sanggup berperan sebagai mediator dan adjudikator sengketa pemilihan yang benar-benar terlatih.

Disamping beragam tantangan di atas, Bawaslu juga terus berupaya untuk secara serius menemukan solusi bagi problem dan tantangan berikut ini ${ }^{9}$ yaitu; pertama, Capacity Building Bawaslu Kabupaten/Kota, Penguatan struktur kelembagaan pengawas pemilu mempunyai arti penting tidak saja terhadap

\footnotetext{
${ }^{9}$ http://rumah pemilu.org, diakses pada tanggal 20 Juni 2018.
}

peningkatan peran dan fungsi pengawas pemilihan di daerah, namun juga memberikan efek positif terhadap aspek psikologis para pengawas di daerah yang selama ini memiliki masalah kepercayaan diri dengan fungsi dan kewenangannya yang bersifat ad-hoc. Perubahan status kelembagaan Panwaslu yang kini bersifat tetap dan berubah nama menjadi Bawaslu memunculkan tantangan baru pula berupa penyiapan dan penguatan aspek sumber daya manusia.

Tahapan pemilihan sudah di depan mata dan banyak beban tanggungjawab yang akan bertumpu di level kabupaten/kota di awal tahapan, ditambah lagi belum terbentuknya lembaga sekertariat yang harus dikepalai oleh pejabat setingkat eselon III. Kondisi ini benar-benar memaksa lembaga ini untuk berjibaku dengan program-program peningkatan kapasitas pengawas pemilihan dari level menengah sampai ke tingkat bawah.

Tidak kalah pentingnya dalam upaya menekan persoalan SDM yang sangat mungkin terjadi maka Bawaslu perlu menerapkan sistem meritokrasi dengan mempertimbangkan aspek-aspek yang dimiliki oleh calon-calon komisionernya yang akan direkrut di daerah, seperti kemampuan teknis dan verbal, pengalaman, mental kepengawasan, 
keahlian, dan terutama integritas. Kombinasi gabungan berdasarkan bidang keilmuan atau latar pengalaman pada unsur keanggotaan Bawaslu juga penting untuk diadaptasikan. Bidang keahlian hukum, komunikasi, politik, kepemiluan, pengalaman keorganisasian dan pengalaman birokrasi akan menjadi kombinasi yang ideal bila disesuaikan dengan kebutuhan divisi yang ada.

Kedua, Pertaruhan Kepercayaan Publik Bawaslu, dimana Bawaslu dengan kewenangannya yang semakin besar sebagaimana yang telah diamanatkan undang-undang maka akan diiringi pula dengan meningkatnya ekspektasi publik terhadap peran lembaga tersebut dalam mengawal pelaksanaan demokrasi di Indonesia. Catatan sejarah pemilu di Indonesia tidak pernah lepas dari permasalahan dan pelanggaran yang kerap mencederai asas dan prinsip pemilu demokratis.

Oleh karena itu posisi Bawaslu akan sangat vital dalam upaya menciptakan kualitas legitimasi hasil pemilihan umum. Tingkat kepercayaan publik terhadap Bawaslu yang bertengger pada angka 71 persen berdasarkan hasil survey yang dirilis Lembaga Survei Indonesia (LSI) bekerja sama dengan lembaga survei asal Washington DC, IFES di penghujung tahun 2013 benar-benar dipertaruhkan pada tahun-tahun politik menjelang pilkada 2018 dan pemilu 2019

Pada tahun 2016 KPU sudah merasakan terpuruknya tingkat kepercayaan publik terhadap lembaga tersebut yang tesungkur di angka 44 persen yang boleh jadi berkorelasi dengan kualitas penyelenggaraan pemilu tahun 2014 Upaya yang paling efektif bagi Bawaslu untuk mempertahankan atau meningkatkan public $\quad$ trust terhadap lembaganya dengan kewenangan yang semakin besar ini tentu saja adalah dengan cara memanfaatkan 'palu hukum' pemilu yang ada dalam genggamannya secara tegas, berefek jera dan berdampak pada aspek pencegahan.

Ketiga, Revitalisasi Tanggungjawab Fungsional Sekertariat, Selama ini ada anggapan umum bahwa dinamika eksternal pada event politik adalah tantangan terberat yang dihadapi Bawaslu sebagai salah satu unsur lembaga penyelenggara pemilu. Padahal sesungguhnya dinamika pada internal lembaga jauh lebih berat menguras energi pada jajarannya. Mencermati berbagai keputusan DKPP terhadap penyelenggara pemilu di daerah khususnya di jajaran Bawaslu/Panwaslu yang ternyata tidak saja menjatuhkan vonis pada komisioner tetapi juga pada para staf pegawai Bawaslu menggambarkan adanya beberapa persoalan di internal tubuh 
kelembagaan yang perlu dihadapi secara arif dan bijaksana.

Persoalan itu terutama menyangkut dosis kewenangan antara komisioner dan sekertariat lembaga yang kadang-kadang saling bergesekan. Hal ini diakibatkan oleh lemahnya pola komunikasi dan pemahaman terhadap wilayah kewenangan dan tanggungjawab masing-masing unsur. Bila tanggungjawab fungsional sekertariat dapat terkontrol dengan baik sehingga dapat dijalankan dengan tepat sesuai ketentuan maka tentunya akan cukup mendukung stabilitas kelembagaan yang diharapkan. Begitupun sebaliknya bila style leadership unsur-unsur pimpinan lembaga mampu menciptakan pola komunikasi dan koordinasi yang lebih luwes maka tentu saja akan memberi kontribusi bagi terwujudnya suasana internal kelembagaan yang kondusif.

Problem berikutnya juga adalah birokrasi sekertariat Bawaslu di daerah masih didominasi oleh staf pegawai yang diperbantukan oleh pemerintah daerah otonom. Kondisi ini membuka celah besar bagi elit dan aktor-aktor politik untuk memanfaatkannya demi kepentingan politik. Para staf yang ditempatkan oleh pemerintah daerah di lembaga Bawaslu memiliki kecenderugan untuk meng'komoditas'kan loyalitas mereka dengan materi atau jabatan kepada pihakpihak tertentu.

Sense of belonging para staf daerah sangat lemah terhadap Bawaslu bahkan mereka dapat membentuk sel kubu tersendiri dalam tubuh lembaga sehingga sangat mengancam soliditas, harmonisasi dan netralitas lembaga penyelenggara pemilu. Bahkan hal ini sangat potensial memunculkan kotak-kotak diametral di tubuh internal lembaga. Penempatan pegawai organik Bawaslu RI adalah solusi teknis agar secara individu para staf sekertariat memiliki tanggungjawab vertikal pada lembaga tingkat pusat.

\section{KESIMPULAN}

Sebagaimana yang dijabarkandi atas, bahwa Bawaslu mempunyai peran yang penting dalam rangka sebagai pengawal Pemilu sesuai dengan yang diamanatkan di dalam Undang-Undang tentang Penyelenggaraan Pemilu, disebutkan bahwa fungsi Pengawas Pemilu yang dijabarkan dalam tugas, wewenang dan kewajiban Pengawas Pemilu. Hal tersebutlah yang perlu diperhatikan dari penunjang untuk memaksimalkan peran Bawaslu sebai fungsi dan perannya untuk penanganan sengketa yang ada dalam Pemilu, selain itu yang perlu diperhatikan bahwa semua pengaduan haruslah melewati satu pintu yaitu Bawaslu. 


\section{DAFTAR PUSTAKA}

Bawaslu, Modul Pengawasan, Badan Pengawas Pemilu-Indonesia

Corruption Watch, Jakarta: Bawaslu, 2009.

Nadir, Ahmad, Pilkada Langsung dan Masa Depan Demokrasi di Indonesia, Malang: Averroes Press. 2005 ,

Reynolds,Andrew,et.al., Desain Sistem Pemilu: Buku Panduan Baru Internasional IDEA, Swedia: International IDEA, 2016.

Soekanto,Soejono, Pengantar Penelitian Hukum, Jakarta: UI Press, 2008.

Undang-Undang Dasar 1945.

Undang-Undang Nomor 18 Tahun 2017 tentang Tata Cara Penyelesaian Sengketa Proses Pemilhan Umum

Undang-Undang Nomor 22 Tahun 2007 tentang Penyelenggaraan Pemilu

Www.pl.bawaslu.go.id/pages/read/sejarahpengawasan-pemilu. diakses pada tanggal 20 Juni 2018

Www.rumahpemilu.org, sdiakses pada tanggal 20 Juni 2018 